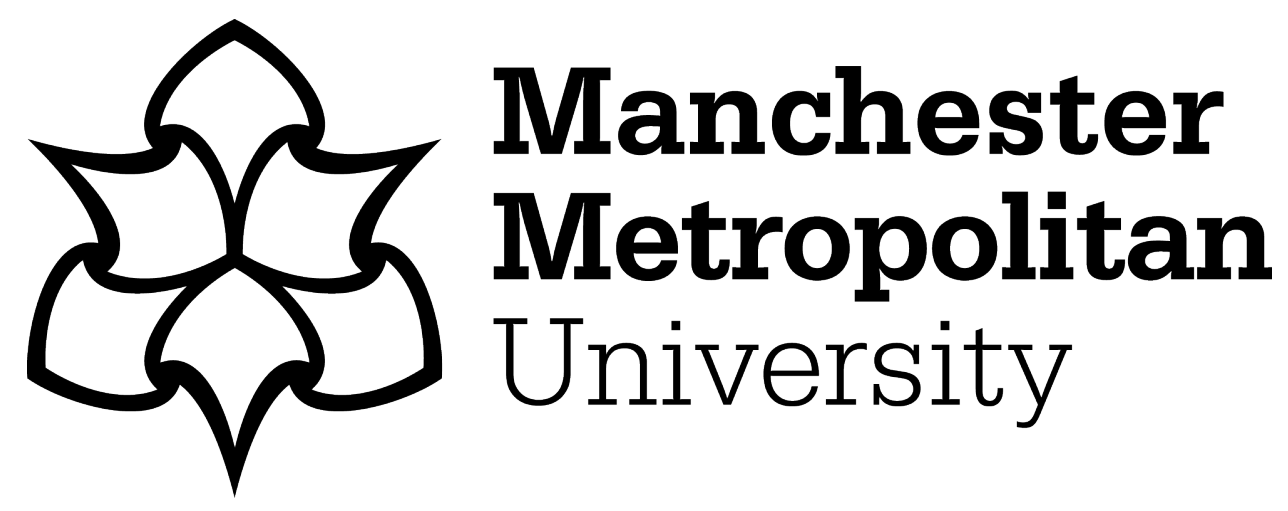

Sissons, Paul and Jones, Katy ORCID logoORCID: https://orcid.org/00000002-8090-4557 (2016) Local industrial strategy and skills policy in England: Assessing the linkages and limitations - a case study of the Sheffield City Deal. Local Economy: The Journal of the Local Economy Policy Unit, 31 (8). pp. 857-872. ISSN 0269-0942

Downloaded from: https://e-space.mmu.ac.uk/623600/

Version: Accepted Version

Publisher: SAGE Publications

DOI: https://doi.org/10.1177/0269094216679602

Please cite the published version 


\title{
Local industrial strategy and skills policy in England: Assessing the linkages and limitations - a case study of the Sheffield City Deal
}

\begin{abstract}
This paper examines changes in local economic development policy which occurred between 2010-2015, with a focus on the relationship between industrial strategy and skills policy. Under the Coalition Government, Local Enterprise Partnerships were established and tasked with facilitating local growth, and to do so many identified a set of (potential) growth sectors for industrial strategy to support. These sectors tended to be drawn from a relatively narrow range of industries which therefore often excluded a large proportion of the local economy. An important focus of the support for growth sectors for many has been through an ambition to influence the local skills system. Skills policy more broadly has been an important dimension of devolution, and a number of City Deals have included elements of skills policy. Echoing previous national policy however, the focus of local concerns with skills under devolution has been framed largely with reference to skills gaps and shortages. While specific skills gaps and shortages can be identified, this paper questions whether this default position is reflected widely, and as such, if a narrow focus on skills supply is a sufficient approach. It is argued that to support local growth across a broad base, greater attention needs to be paid to stimulating employer demand for skills through better integrating industrial and innovation policy with skills policymaking across a wider section of the local economy. To support these arguments we present a case study of the Sheffield City Deal.
\end{abstract}

Keywords: Skills policy, Industrial Strategy, City Deals, Local Enterprise Partnerships, Sheffield City Region

\section{1) Introduction}

When the Coalition Government came to power in 2010 significant changes were introduced to the institutional framework around local economic development. The Regional Development Agencies (RDAs) were replaced with business-led Local Enterprise Partnerships (LEPs). Further changes saw the agreement of 'City Deals' and 'Growth Deals' between national Government and some English Cities which included devolution of powers and resources in specific policy areas. The focus of this paper is on policy under the Coalition Government (2010-2015), however the trend towards greater devolution has been extended in the period since the election of a Conservative Government (2015) in terms of the scale of resources and the areas of policy covered.

The rationale for the move towards more devolution, particularly to cities, was described by the Coalition Government as:

'to unlock [cities'] full potential we need a major shift in the powers available to local leaders and businesses to drive economic growth'

(Clegg, 2011). 
These developments built on a groundswell of opinion among many stakeholders that greater devolution of powers to cities and local areas is desirable and has the potential to increase economic growth. The Heseltine Review (2012) called for a 'very significant devolution of funding from central government to Local Enterprise Partnerships' (page 9). In response to calls for greater devolution, mechanisms were developed to begin to devolve powers to local areas. This process represented the start of a gradual (and uneven) transfer of powers towards more localised control of particular areas of economic development policy (O’Brien and Pike, 2015).

In Sheffield, which is presented as a case study in this paper, agreed devolution of powers over local economic growth has given Sheffield City Region LEP and Combined Authority more control over elements of skills, employment, business support, transport and housing policy (Clark, 2014). In this paper the focus is on the initial devolution settlement agreed through the Sheffield City Deal. Since this agreement, other strands of devolution have included the agreement of Growth Deals focused on transport and housing, skills and business support; ${ }^{\mathrm{i}}$; and most recently the Sheffield City Region Devolution Agreement which providers further devolved powers in relation to these areas of policy.

While there is a quite pervasive policy narrative of cities as drivers of growth, the empirical evidence from cities outside the Greater South East on both economic and employment growth outcomes is more mixed (Champion and Townsend, 2011; Lee et al, 2014). Commentators have also questioned how meaningful early iterations of localisation were under the Coalition. The transition from RDAs to LEPs has been characterised by greater localisation of some powers but by re-nationalisation of others (Peck et al, 2013).

As well as a growing interest in devolution, in the latter years of the Labour Government, and during the period of Coalition Government, there was something of a revival of interest in industrial policy and industrial strategy at both national and local levels. Whilst unpopular during the Thatcher and post-Thatcher years, the onset of the financial crisis saw renewed interest and an emerging policy consensus around the need for a UK industrial strategy (Mayhew and Keep, 2014). This was driven both by a need to stimulate economic growth and to meet the aspiration to rebalance the economy geographically and sectorally.

In a 2008 speech, Peter Mandelson, the then business secretary called for "market-driven industrial activism" "ii , and on coming into office the Coalition government continued to pursue an active industrial strategy (HM Government, 2014). The strategy centred on five core components; skills, technologies, access to finance, government procurement and sector partnerships (Ibid). Under the current Theresa May government, industrial strategy also appears to have traction. Although it is as yet unclear what form this support might take, the renaming of government departments to The Department for 
Business, Energy and Industrial Strategy (BEIS) suggests something of a priority is being attached to industrial strategy.

It has however been argued that the 'new' industrial strategy has been too narrowly designed, with policy focused on a small number of sectors and ignoring the vast bulk of economic activity (Mayhew and Keep, 2014). By international standards, the UK labour market exhibits a relatively long-tail of low-wage employment; this work is often characterised by its limited demand for skills (Ray et al, 2014; Sissons and Jones, 2014). Yet industrial strategy aimed at targeting these issues remains largely undeveloped.

Skills policy has been viewed as an important factor underpinning industrial strategy success, with a particular emphasis on developing technical skills (HM Government, 2014). The focus here has been primarily on supply-side skills interventions (i.e. improving skill levels). This has led to criticism that UK industrial strategy is unbalanced and lacks:

'a coherent, integrated strategy that embraces growth, skills, innovation, employment relations and the labour market - that is, the demand side of the skills equation' (Mayhew and Keep, 2014; page 7).

In this paper we assess institutional changes around local economic development between 2010 and 2015 alongside wider changes in skills policy in England. The aim is to examine what these changes have meant for local industrial strategies and the role which skills policy plays in supporting this. We argue that the preoccupation with skills gaps and shortages and a narrow range of sectors expressed in local strategies fails to fully understand the nature of the skills problem, and as such mirrors wider fallings in national skills policy.

The paper is structured as follows. Section 2 describes the evolution of skills policy in the UK over the past decade. Section 3 examines changes in sub-national approaches to industrial strategy and the implications of this for skills policy. Section 4 explores the linkages between local industrial strategy and local skills policy. Section 5 presents a case study of changes in local industrial strategy and skills policy using the example of the Sheffield City Deal. Section 6 provides conclusions and policy implications.

\section{2) Skills policy in England: from Leitch to Cable}

The Leitch Review of skills, which was published in 2006, highlighted that the skills profile of the UK lagged behind that of a number of competitor nations. As a result a number of ambitious targets where adopted by the then Labour Government to drive improvements to the UK's skills profile and make the country a 'world leader in skills by 2020' (Leitch, 2006). This included aims to significantly increase the proportion of the population with skills at all levels from NVQ 2 upwards (Ibid). In the period since, skills policy has been a central element of strategies aimed at boosting competitiveness and productivity (UKCES, 2010). Skills investment has also been viewed as a vehicle to 
pursue wider social goals including greater social inclusion and increased social mobility (Green, 2012).

In the period following the publication of the Leitch Review large amounts of public investment were made available to expand education and training opportunities (Payne and Keep, 2011); and a number of mechanisms were introduced to help support meeting the targets. This included the introduction of local Employment and Skills Boards (ESBs), public-private partnerships developed to provide strategic direction on skills policy decision-making. It also included the establishment of Train to Gain, a programme which was aimed at supporting greater levels of attainment of vocational qualifications for low-skilled workers. Train to Gain provided quite generous subsidies to encourage training and supported large numbers of workers to gain additional qualifications. The programme was however discontinued by the Coalition Government who argued that it was too costly and suffered from a significant degree of deadweight (see National Audit Office, 2009).

Under the Conservative-Liberal Coalition (2010-2015) a number of changes were introduced to skills policy. Adult skills experienced considerable reductions in public funding, while policy also shifted away from central targets, including scrapping the Leitch targets (Green, 2012). Other measures for skills were laid out in the White Paper Skills for Sustainable Growth (BIS, 2010). These included developing a new framework to support better leadership and management through work with partners including the Trades Union Congress, Business in the Community and the Charted Institute for Personnel and Development; promoting 'Investors in People', an established national standard for evaluating firms' staff development; establishing a Growth and Innovation Fund (GIF) to support employer-led projects to increase investment in skills, working on a competitive basis; and, trialling Employer Ownership of Skills Pilots which develop models of co-investment with firms and sectors (also on competitive basis). Largely, these measures were designed to put more emphasis on demand-led funding. A number of risks however have been highlighted relating to the routing of skills funding more directly through employers, these include concerns about deadweight, creating a reliance on public funding and a concern about the narrowing of skills provision (Froy, 2013).

In addition to developing new models to encourage employers to take greater 'ownership' of the skills system there was also the introduction of some new devolution of powers and responsibilities to local areas. This includes through mechanisms such as City Deals (which are discussed subsequently). Most recently, changes have been announced to the apprenticeship system. These changes include the proposed introduction of an Apprenticeship Levy (to begin in Spring 2017). The aim of the levy is to expand the number of quality apprenticeships available with employers with a wage bill exceeding $£ 3$ million a year being subject to the levy.

Skills policy in England has had a predominant focus on skills supply at both national and sub-national levels, and there is a large literature which evidences the importance of skills levels to a local area's labour market performance (for a brief overview see Lee et 
al, 2014). However surveys suggest that the UK also has a problem related to demand for skills (Employer Skills Survey, 2007; 2009; 2011; 2013). A weakness in demand for skills has implications for the under-utilisation of skills in the workplace, as well as potentially for local migration and unemployment.

In the UK almost half of business establishments report having staff who are both overqualified and over-skilled for their current post, this equates to some 4.3 million workers (16 per cent of the workforce) with under-used skills (UKCES, 2014). The under-use of skills therefore affects a considerably larger proportion of employers, and of the workforce, than skills deficiencies do. The level of reported under-utilisation in the UK is high by international standards (OECD, 2012). While over the longer-term it has been demonstrated that although the proportion of the workforce with no qualifications has fallen significantly, the decline in the number of jobs requiring no qualifications has been substantially smaller (Felstead et al, 2007).

The scale of skills under-utilisation varies by sector. Figure 1 presents data from the Employer Skills Survey (ESS) on the under-use of skills. The survey asks employers to report on 'how many staff, if any, had both qualifications and skills that are more advanced than required for their current job role' (Winterbotham et al, 2014; 49). In 2013, the highest proportion of businesses reporting skills under-use were those in the hotels and restaurants sector ( 60 per cent). The lowest incidence of skills under-use was in agriculture and manufacturing sectors (38 and 39 per cent respectively). The proportion of employees within a sector with an under-use of skills is also highest in the hotels and restaurants sector ( 24 per cent) followed by community social and personal service activities (21 per cent).

Figure 1, Employer Skills Survey 2013: UK Results

\begin{tabular}{|l|c|c|}
\hline Sector & $\begin{array}{l}\text { Per cent of establishments } \\
\text { reporting skills under-use }\end{array}$ & $\begin{array}{l}\text { Per cent of staff in sector } \\
\text { with skills under-use }\end{array}$ \\
\hline Hotels and restaurants & 60 & 24 \\
\hline Education & 54 & 12 \\
\hline Public Administration & 53 & 21 \\
\hline Health and Social Work & 53 & 19 \\
\hline $\begin{array}{l}\text { Community, Social and } \\
\text { Personal Service activities }\end{array}$ & 52 & 12 \\
\hline Wholesale and retail & 50 & 13 \\
\hline Financial Services & 50 & 15 \\
\hline Electricity, gas and water & 45 & 16 \\
\hline $\begin{array}{l}\text { Transport and } \\
\text { communications }\end{array}$ & 44 & 6 \\
\hline Business Services & 44 & 14 \\
\hline Mining and quarrying & 41 & 10 \\
\hline Construction & 40 & 39 \\
\hline Manufacturing & & \\
\hline
\end{tabular}




\begin{tabular}{|l|l|c|}
\hline Agriculture & 38 & 19 \\
\hline
\end{tabular}

(Source: UKCES Employer Skills Survey)

While the issue of the under-use of skills is now more often mentioned in official documents, practical policies around addressing this have been more limited (Keep and Mayhew, 2014). Policymakers have been reluctant to engage with demand-side policy because this would be seen to intervene in the 'black-box' of the workplace (Keep et al, 2006; Green, 2009; Wright and Sissons; 2012; Keep, 2013). The net result of this has been an insufficient emphasis on seeking to stimulate greater employer demand for skills, encourage better skills utilisation and boost workplace innovation (Mayhew and Keep, 2014). In particular, there is an important link between business strategy and demand for and use of skills (Sung and Aston, 2014). Business strategy is shaped by the wider business environment, which in turn is influenced by elements of public policy such as institutional factors, regulation and incentives in addition to skills supply, yet these other factors are under-considered (Ibid.)

In England, what policy focus there has been on employer demand for skills has been largely driven by the United Kingdom Commission for Employment and Skills (UKCES) $)^{\text {iii. }}$. The focus of the UKCES approach has been on encouraging employers to develop and use high-performance working practices (HPW) (CFE, 2008). HPW is a broad suite of practices and can include activities in the areas of human resource management, management and leadership and organisational development, with the aim being to help improve firm performance. HPW is concerned with increasing and effectively using the knowledge, skills and ability of employees (SQW, 2013); as such, an important component of HPW is the fuller utilisation of employee skills (Belt and Giles, 2009). However, there are a number of important limitations to the development and success of the HPW approach in England. The take-up of HPW practices by employers is relatively limited and the impact of practices is unclear (see Keep, 2013 for a summary).

More broadly there are limits to what skills policy can do in isolation to address economic and labour market issues, even where it is well-designed (Keep et al 2006). Factors other than skills can often be more important components of productivity growth for individual firms (Ashton and Sung, 2011). While for social concerns such as low-pay, better skills policy is not a silver bullet and needs to be combined with a range of other measures aimed at improving wages and working conditions (Payne, 2007; Lloyd and Mayhew, 2010; Wright and Sissons, 2011)

\section{3) Industrial strategy - sub-national approaches}

When the Coalition Government came to power they introduced some significant changes to sub-national economic development policy. One of the first acts of the Coalition was to abolish the Regional Development Agencies (RDAs) which held responsibility for the regional tier of economic development. The RDAs were succeeded 
by (geographically) smaller and business-led Local Enterprise Partnerships (LEPs). LEPs were designed in theory to approximate 'functional economic areas'. In 2014 there were 39 LEPs, of varying size, covering England.

The establishment of LEPs was criticised for a number of reasons. Their introduction was simultaneously associated with a movement of some additional power and responsibilities to local areas but also the centralising of some functions previously held by the RDAs, including aspects of inward investment, innovation and SME development policies (Bentley et al, 2010; Hildreth and Bailey, 2010). More generally the closure of the RDAs has been associated with a significant reduction in resources for economic development activities, creating doubts about their ability to drive local growth (Hayman, 2012; Payne and Keep, 2011). Commentators also highlighted the distinctly uneven playing field among LEPs in terms of their rates of economic growth potential and skill bases (Crowley et al, 2012).

Whilst LEPs were designed to offer an opportunity for a more tailored approach to industrial strategy, there appears to have only been partial success in identifying key sectors based on different local competitive advantages. Rather, LEPs have tended to focus on a narrow range of 'fashionable' growth sectors such as creative and digital, the visitor economy, advanced manufacturing, business and professional services, life sciences, and low carbon/renewable energy (Peck et al 2013).

The convergence of LEP strategies has been taken to support the notion that 'LEPs lack the capacity to engage in broad-based sectoral interventions' (Peck et al, 2013: 832), and this is thought to in part reflect a decline in the number of national growth sectors, an emphasis on promoting inward investment, and cuts to local government (i.e. economic development staff), which has reduced capacity and local economic knowledge (CLES, undated).

New possibilities for developing and supporting local industrial strategies were however opened up through mechanisms aimed at devolving selected powers to local areas.

City leaders were invited to make proposals for 'City Deals' to central government which would involve the devolution of some negotiated new powers and resources to individual cities (Crowley, 2012). The first wave of City Deals, which were agreed in 2012, were focused on the eight largest cities outside London. Subsequently, a second wave of Deals were agreed with seventeen smaller and fast growing cities. The City Deals included 'asks' of Central Government in the form of requests for devolution of particular funding streams and/or powers in specific policy areas. They also contained a set of commitments from the cities themselves to undertake certain actions or to commit specified resources themselves. A number of the City Deals included elements of skills and employment policy. Many also specified sectors viewed as being of importance locally.

Building on LEP Growth Plans and in recognition of the 'step-change' required, Strategic Economic Plans (SEPs) were then used to negotiate Growth Deals. In July 
2014 the Government announced a first wave of Growth Deals. These brought together housing, infrastructure and other funding into a single pot, with LEPs having control over the way in which the money is spent. Through these, LEPs negotiated new freedoms, flexibilities and influence over government resources, and a share of the Local Growth Fund to target their identified growth priorities.

Subsequently more wide-ranging options for devolution have been established through agreement of 'devolution deals' and through new legislation of the Cities and Local Government Devolution Act 2016. New devolution settlements have moved at a different pace across cities. The powers are relatively wide-ranging but include elements of infrastructure and transport, housing and skills. A number of deals also agree greater local influence over elements of health services and employment programmes.

Agreements have also included provisions for governance changes and the establishment of a directly elected Mayoral model.

\section{4) Linking local industrial strategy and skills policy}

The local is important in skills policy because at the local level it can be linked with other local and regional strategies aimed driving economic development (Payne and Keep, 2011; Green, 2012). There is therefore a strong rationale for linking industrial strategy and skills policies locally. In this vein, many LEPs made skills a key priority, with universities and further education colleges commonly represented on LEP boards. However in the majority of cases LEPs anchored the skills needs of local industrial strategies almost exclusively in concerns about the supply of skills. In particular, the dominant framing has tended to be around skills shortages and skills gaps. In this respect the approach taken to skills is relatively unbalanced.

Research has however increasingly highlighted the importance of employer demand for skills and the ways in which skills are used in the workplace as critical elements of local economic development (Froy et al, 2009; Sissons and Jones, 2014; Mayhew and Keep, 2014). The work of the OECD through the Local Economic and Employment Development (LEED) programme (an international knowledge exchange programme which has core aims of boosting local employment creation and developing more inclusive labour markets), has been influential in pressing this case (see Froy et al, 2009; Froy, 2013). This focus is important because the balance between supply and demand for skills has important implications for local economic success.

One way of considering skills problems locally is through the concept of skills equilibria and the local balance between demand and supply for skills. Work by Green (2012) has developed a diagnostic tool to benchmark local skills performance using local labour market and skills data. These data are designed to represent the 'average condition' in local labour markets ${ }^{\mathrm{iv}}$. The ways that skills supply and demand are linked is set out in Figure 2. The quadrants describe: 
- 'Low skills equilibrium - a situation of low supply and of low demand for skills;

- Skills gaps and shortages - a situation of low supply and high demand for skills;

- Skills surplus - a situation of high supply and low demand for skills; and

- High skills equilibrium - a situation of high supply and high demand for skills'

(Green, 2012; 5).

Figure 2: Low and high-skills equilibria

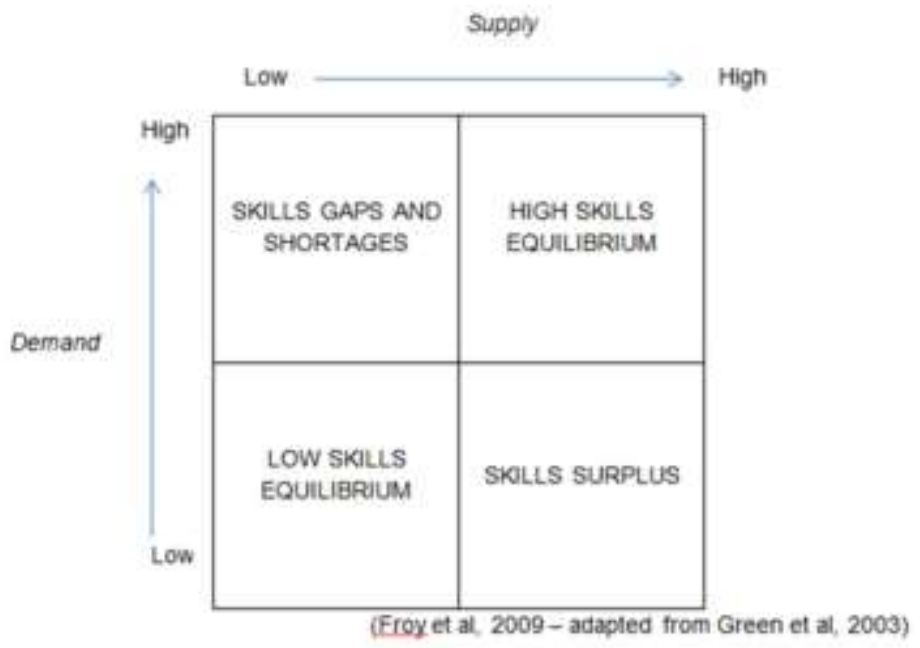

Where skills gaps and shortages are affecting a local economy then greater investment or efficiency in skills supply is needed. Where local economies are in a low skills equilibrium, which is characterised by a predominance of low value added firms, policy should seek to increase employer demand for skills as well as improving skills supply. When local areas have a skills surplus, policies to support better skills utilisation may be appropriate.

These issues are important because weak employer demand for skills and the way that skills are used in the workplace are important factors in low-wage employment (Payne and Keep, 2011). Low-wage work can be associated with low-road product market strategies at firm level (Ashton and Sung, 2011); and low-wage jobs are often designed in such a way which seeks to limit worker use of skills (Newton et al, 2006). Concerns about the issue of a low skills equilibrium in the UK national economy were first articulated more than two decades ago (Finegold and Soskice, 1988; see also Wilson and Hogarth, 2003). However, policy has been painfully slow to address the issue (Payne and Keep, 2011).

Patterns in the relationship between supply and demand for skills are also spatially uneven; with low skills equibria more likely to be found in former industrial towns and cities and some rural areas (Green, 2012). This is important for policy because at the local level a low skills equilibrium is likely to be associated with a significant proportion of firms operating with low value added strategies and paying low wages (Ibid). These geographical patterns of unevenness in the relationship between skills supply and 
demand partly reflect wider patterns of spatially uneven development and differences in the sectoral and occupational composition of local labour markets.

Policymakers can seek to influence local skills demand either by seeking to attract inward investment from more knowledge-intensive employers, or by supporting local employers to adopt more knowledge-intensive production processes. There are a range of approaches that policymakers might use, including the provision of guidance, technical assistance and management training, and through incentivising inter-firm collaboration and networking (in order to facilitate the sharing of new technologies and innovations and pool training investments) (OECD, 2014). The public sector can also lead by example_through employment practices, along with influencing skills demand in its supply chains through procurement processes (Ibid.).

The OECD's LEED programme provides several examples of using local skills strategies to support the upgrading of product market strategies including in the food-processing sector (Niagara, Canada) and the footwear sector (Reviera del Brenta, Italy) (Froy, et al., 2012). The Niagara example demonstrates the additional skills needs associated with upgrading product market strategies; as well as providing an example of the integration of supply and demand focused policy, with local education providers being 'engaged actively in stimulating productivity and increasing the utilisation of skills by employers' (Page 41). The Reviera del Brenta example demonstrates the important role which local education institutions can play in supporting (including through technical research) the transition to higher value-added product market strategies, the study also demonstrates the important role which unions can play in ensuring greater productivity translates in improved job quality for workers (Ibid.)

There is other evidence of practice around better skills utilisation and integration skills and economic development policy from across a range of countries (see CFE [2008] for an overview). A longstanding example is the work of the Finnish Workplace Development Programme (1996-2003) which supported 670 projects that had the dual aim of increasing productivity and quality of life (or 'sustainable productivity growth) (Payne, 2004). In Australia, the skills ecosystem project was developed to better link skills development with wider business and economic development. This included funding projects addressing a range of job quality and competitiveness concerns and included approaches to vocational and educational training, efforts at reshaping jobs and labour markets, and seeking quality improvement across supply chains (see CFE, 2008; Buchanan, et al., 2010).

\section{5) The case of the Sheffield City Deal}

The issues relating to industrial strategy and the balance of focus between skills supply and demand are now explored with reference to policy changes in the Sheffield City Region associated with the agreement of a City Deal with central Government. Sheffield is selected as it represents an early example of devolution of skills policy from central Government, including developing approaches for apprenticeships and for adult skills 
policy. The orientation of skills policy developed through this early round of devolution may be considered indicative of the direction of travel of skills policy at a local level, and allows for consideration of the extent to which devolved skills policy can be effectively shaped to meet local needs, including those relating to both skills supply and demand. The case study of the Sheffield City Deal presented here is based on review and analysis of local documents relating to the City Deal and to skills and economic development in the City Region.

The Sheffield City Region Local Enterprise Partnership (LEP) established an important role around influencing the skills agenda in the Sheffield City Region, with skills being one of the LEP's priority 'workstreams 'v . Sheffield City Region was also in the first wave of cities to agree a City Deal. The City Deal included four main strands:

- Skills for growth - including up-skilling existing employees and creating apprenticeships

- Financial tools for growth - establishing a regional investment fund which pools funding streams

- Transport - increasing connectivity and bringing forward investment in key projects

- Advanced manufacturing and procurement - developing a national centre for procurement in advanced manufacturing and nuclear research

The Sheffield City LEP, which agreed the Deal, covers nine local authorities with a combined population of around 1.75 million people ${ }^{\mathrm{vi}}$, these are:

- Barnsley

- Bassetlaw

- Bolsover

- Chesterfield

- Derbyshire Dales

- Doncaster

- North East Derbyshire

- Rotherham

- Sheffield

As part of the Deal the City Region secured an additional $£ 4$ million in funding from central government for skills provision, with $£ 23.8$ million from national adult skills and apprenticeships budgets also being channelled to the local area. The Deal also includeds a local co-funding commitment of $£_{6} 6-12$ million from the local authorities and a minimum of $£ 37.5$ million of employer co-investment.

Evidence from Green (2012), developed as part of the OECD LEED programme, allows for some analysis of the dominant skills issues affecting the City Region. This 
work develops an indicator of the balance between skills supply and demand at the local level using information on qualifications (supply) and Gross Value Added (GVA) per worker and occupational composition (demand). The data are a 'broad brush' approach rather than a detailed local treatment but do allow for some comparison between local areas (with the data covering the year 2009). The data are based on European Statistical areas (NUTS 3) so do not match precisely to the definition of the City Region, however it does allow for parts of the City Region to be analysed in isolation. The data suggest that the Sheffield City area has somewhat lower demand for skills compared to the supply of skills. This indicates some under-utilisation of skills locally. The Barnsley, Doncaster and Rotherham area scores poorly for the demand of skills, as well as for the supply of skills. This indicates a low skills equilibrium in this part of the City Region. Taken together the data suggest a need for local policy to focus on demand for, as well as supply of, skills.

Projections suggest new jobs growth in the City Region is expected in the business services sector, construction, and transport, as well as in other parts of the service sector, health and low carbon industries (Ekosgen, 2012). By contrast, employment in manufacturing, public administration and education are expected to decline (Eksogen, 2012). The City Deal documents also highlight a number of sectors which form Sheffield City Region's industrial strategy or priorities, these are advanced manufacturing, healthcare technologies, low carbon industries and creative and digital technologies (MADE in Sheffield, 2012; page 8). Within the City Deal proposal documents the rationale for selection of these sectors is not articulated. While the sectors in part map onto employment growth projections the employment footprint of them is relatively small and the subsequent publication of the local LEP Economic Overview expanded to then cover nine priority sectors.

The core aim of the skills element of the City Deal is outlined in the intention to create a:
'demand-led skills system which provides employers with a work-force able to meet their growth aspirations, and which secures significant new investment and engagement from employers in return' (Page 4).

The local skills problem is therefore framed as relating to the supply of skills, with the existing workforce 'not adequately skilled to take up new opportunities' despite large scale government investment in skills over the past decade (Page 9).

The skills element of the City Deal focuses on two main strands. First, an apprenticeship strand aiming to grow the number of young people in apprenticeships locally. This built on a model, Opportunity Sheffield, which had been developed previously by Sheffield City Council. The rationale and aims for this strand are both economic and social, concerned both with the provision of a better skills base locally, and a more explicit social aim of tackling comparatively high levels of youth unemployment in the City Region. The delivery model designed to support this strand involved the creation of a City Region Hub including an Apprenticeships Training Agency, as well as supporting 
Group Training Associations to help facilitate the participation of Small and Medium Enterprises (SMEs), many of which cannot afford to employ full-time apprentices.

The second delivery strand focused on adult skills. Again building on previous local practice developed by the City of Sheffield, the programme is delivered through a group of intermediaries and skills providers. The intermediaries focus is on employer engagement, and through discussions they seek to identify where employers have skills gaps or training needs. The programme is also targeted at Small and Medium Enterprises (SMEs), with the particular aim of engaging firms who have not previously, or do not tend to, engage with publicly funded training provision. The type and level of upskilling for adults in employment is not specified by the programme administration and there is a relatively large degree of flexibility over how training funding can be spent.

The skills strands of the City Deal are relatively broad in terms of sector orientation and there is scope for sectors to change over time. The sectors targeted initially by intermediary organisations include those identified in the City Deal as key strengths as well as a number of target sectors which labour market intelligence suggests are likely to generate large numbers of job openings. In this sense the programme seeks to achieve a dual aim of both supporting industrial strategy but also targeting inclusion outcomes. The sectors selected to be targeted by the programme are ${ }^{\text {vii: }}$

- Business, finance, creative digital, and ICT

- Engineering, advanced manufacturing and construction ${ }^{\text {viii }}$

- Hospitality, retail and logistics

- Care

The delivery of the City Deal raises a number of important learning points for consideration in developing local skills policies going forward. The case highlights an important question facing local areas about how best to diagnose and respond to dominant skills issues in specific local areas and in different sectors. The City Deal is developed to be 'employer-led', with skills provision targeting the 'skills gaps' identified by local employers (or through intermediary organisations). While some specific skills gaps can be identified in the City Region it is not the case that the dominant skills issue faced by a number of the target sectors - for example in care, hospitality and retail - is one of skills gaps. Rather, national evidence suggests it is most often the under-utilisation of skills in these sectors that is reported. Related issues of low-pay and poor career progression are also widely apparent. Yet the issue of weak demand for skills, or the challenges faced by low-earners in these sectors more generally, is absent from the City Deal. The City Deal therefore highlights the difficulty, but also the need, to understand that dominant skills needs within different sectors are likely to vary, and that a single delivery model (even one with flexibility in skills provision) will not necessarily address core sector needs. It also highlights the need to consider a more balanced set of skills policies which target improvements to both skills supply and demand. As described, previous work has found that within different parts of the City Region the dominant 
skills issues appear to be around skills under-utilisation and low-skills equilibrium, but the City Deal programme does not seek to address these.

The City Deal programme also highlights the tension between developing policy to support high value added versus high employment sectors. Both types of sector will be important economically and socially, and the City Deal's relatively broad design reflects this in terms of the scope of sectors covered. However, a consideration of the scope for improving outcomes within large employment sectors, which seeks to address wage levels and/or opportunities for career progression is missing from the programme.

The operation of skills elements of the City Deal are also relatively non-discretionary. They attempt to engage a wide selection of employers, with the emphasis on SMEs who have not recently engaged with skills provision. However given constraints on resources there is a question about whether more tightly defined ways of targeting could have been developed. Other ways of targeting could be to seek to support growing firms, firms with potential for growth, or firms creating 'good jobs'. This type of targeting may also go further towards shaping as well as responding to demand.

Finally there is also a wider question about the integration of local services and strategies. While the sectors targeted by the skills strands are influenced by local industrial strategy there is little evidence of the linkages in practice between the skills offer developed and wider economic development, as well as innovation and business support policies. Overall, the evidence suggests that the Sheffield City Deal is only a partial treatment of the area's skills issues. In particular, it gives insufficient consideration to the demand side of the skills equation.

\section{6) Conclusions and policy implications}

When the Coalition government came to power in 2010 some significant changes were made to local economic development policy. Regional Development Agencies were replaced with Local Enterprise Partnerships and new mechanisms for devolution of powers were developed through negotiated City Deals and Growth Deals. Since the recession there has also been a reinvigoration of interest in industrial strategy as a means of pursuing growth and rebalancing the economy. As such many LEPs identified a set of (potential) growth sectors locally. However these sectors have tended to be drawn from a relatively narrow pool.

An important way in which LEPs have aimed to support emergent industrial strategies is through local skills policy. New opportunities have opened-up for ways to influence skills practice locally and the City Deals are an example of this. The discourse around skills needs both for industrial strategy and more broadly has been strongly bound up with the perception of skills gaps and shortages as an important inhibiter of growth. In this respect local orientations are largely a continuation of national skills policy which has focused in large part on skills supply but with less consideration for identifying ways to support increasing employer demand for skills. Yet the balance of policy attention on 
skills supply vis-à-vis demand is important for local economic outcomes. Weak employer demand for skills can be associated with the under-use of workforce skills or with a local low skills equilibrium and a predominance of low-paid poor quality work. The UK has a high proportion of low-waged work by international standards as well as a high incidence of the under-utilisation of skills. However emerging local skills strategies have paid insufficient attention to the issues of employer demand for skills, job design and workplace innovation.

This lack of balance in skills policies can be seen in the case study of the Sheffield City Deal. As part of their City Deal, the Sheffield City Region LEP negotiated some new devolution of skills funding and powers. These are targeted at both apprenticeships and adult skills with the aim of making the skills system more 'employer-led'. The sectors targeted for support include those identified in local industrial strategy as being potentially most valuable economically as well as a number of sectors which are likely to generate large volumes of job openings. The design of the City Deal is to focus on skills gaps identified by local employers. However in many sectors which the programme targets, such as care, hospitality and retail, it tends not to be skills gaps but rather the under-utilisation of workforce skills which tends to be the dominant issue, as well as related concerns about low-pay and poor career progression.

In many respects the challenges (and proposed solutions) of local areas reflect those previously experienced nationally. Local industrial strategies have tended to focus on a narrow range of sectors. Skills policy has been fashioned to support industrial strategy but with a dual role around social outcomes which has also focused on high employment sectors. However this focus has been dominated by the supply side and the predominant concerns about skills gaps and skills shortages. While addressing skills gaps and shortages is important, little consideration has been given to the broader problem of weak demand for skills across a range of sectors. To address the long-tail of low-skilled and low-paid work in the UK, both industrial strategy and employment and skills policy need to consider this issue in a more meaningful way.

Since the election of a Conservative Government in 2015 the devolution agenda has continued to evolve. New powers and resources are also being devolved and different models of governance are developing. The extent to which new models of devolution support local growth and inclusion is an important area for future research. 


\section{Bibliography}

Ashton D and Sung J (2011) Product Market Strategies and Skills Utilisation. Glasgow: Skills Development Scotland

Ashton D and Sung J (2011) Productivity and Skills. Glasgow: Skills development Scotland

Belt V and Giles L (2009) High Performance Working: A Synthesis of Key Literature Wath-onDearne: UK Commission for Employment and Skills.

Bentley G, Bailey D and Shutt J (2010) From RDAs to LEPs: A New Localism? Case Examples of West Midlands and Yorkshire Local Economy 25: 535-557.

Buchanan, J. et al. (2010) Skills Demand and Utilisation: An International Review of Approaches to Measurement and Policy Development. OECD Local Economic and Employment Development Working Papers, Paris: OECD

CFE (2008) Skills Utilisation Literature Review Scottish Government Social Research

Champion T and Townsend A (2011) The Fluctuating Record of Economic Regeneration in England's Second-order City-regions, 1984-2007 Urban Studies 48 (8): 1539-1562.

Clark G (2014) City Deal: Written statement - HCWS141 Available at: http://bit.ly/1zszLpF (accessed 23/12/2014)

Clegg N (2011) Foreword to Unlocking Growth in Cities. HM Government Available at: http://www.dpm.cabinetoffice.gov.uk/sites/default/files_dpm/resources/CO_ Unlocking\%20GrowthCities_acc.pdf (accessed 2 December 2014)

CLES (undated) The local economic resilience of LEPs Available at: http://www.cles.org.uk/wp-content/uploads/2014/04/Assessing-the-resilienceof-LEPs-final.pdf (accessed 12 November 2014)

Crowley L, Balaram, B and Lee N (2012) People or Place? Urban policy in an age of austerity London: The Work Foundation

Department for Business, Innovation and Skills (2010) Skills for sustainable growth BIS Strategy Document

Eksogen (2012) Skills Research in Sheffield City Region. Available at: http://www.enhancementfund.co.uk/uploads/files/Sheffield\%20LEP\%20Repor t.pdf (accessed 13 November 2014)

Felstead A, Gallie D, Green F and Zhou Y (2007) Skills at Work, 1986-2006 Oxford: University of Oxford

Finegold D and Soskice D (1988) The failure of training in Britain Oxford Review of Economic Policy, 4 (3): 21-53. 
Froy F (2013) Global policy developments towards industrial policy and skills: skills for competitiveness and growth Oxford Review of Economic Policy 29(2): 344-360.

Froy F, Giguère S and Hofer A (2009) Designing local skills strategies OECD Publishing, Paris

Green A (2012) Skills for Competitiveness: Country Report for United Kingdom, OECD Local Economic and Employment Development (LEED) Working Papers, 2012/05, OECD Publishing. http://dx.doi.org/10.1787/5k9bb1vc6skf-en

Green A, Sissons P, De Hoyos M, Broughton K (2015) Linking jobs and poverty in cities York: Joseph Rowntree Foundation

Green F (2009) Job Quality in Britain London: UKCES

Hayman A (2012) Local Government and Growth, in Changing Gear-is localism the new regionalism? London: The Smith Institute and Regional Studies Association

Heseltine M (2012) No stone unturned in pursuit of growth London: HM Government

Hildreth P and Bailey D (2010) The economics behind the move to Local Enterprise Partnerships. SURGE Working Paper 2. SURGE: Coventry

HM Government (2013) Growth Deals: Initial Guidance for Local Enterprise Partnerships Available at: https://www.gov.uk/government/uploads/system/uploads/attachment_data/fil e/224776/13-1056-growth-deals-initial-guidance-for-local-enterprisepartnerships.pdf (accessed 10 October 2014)

HM Government (2014) Industrial strategy: Government and industry in partnership: Progress report Available at: https://www.gov.uk/government/uploads/system/uploads/attachment_data/fil e/306854/bis-14-707-industrial-strategy-progress-report.pdf (accessed 13 December 2014)

Keep E (2013) Opening the 'Black Box' - the increasing importance of a public policy focus on what happens in the workplace Glasgow: Skills Development Scotland

Keep E, Mayhew K and Payne J (2006) From skills revolution to productivity miracle not as easy as it sounds? Oxford Review of Economic Policy 22(4): 539-559.

Lee N, Sissons P, Hughes C, Green A, Atfield G, Adam D and Rodríguez-Pose A (2014) Cities, growth and poverty: A review of the evidence. Joseph Rowntree Foundation

Leitch S (2006) Prosperity for all in the global economy-world class skills London: HM Treasury

Lloyd C and Mayhew K (2010) Skill: the solution to low wage work? Industrial Relations Journal 41(5): 429-445. 
MADE in Sheffield- a deal for growth

http://www.dpm.cabinetoffice.gov.uk/sites/default/files_dpm/resources/Sheffi eld-City-Deal-Final.pdf (accessed 17 April 2013)

Mayhew K and Keep E (2014) Industrial strategy and the future of skills policy: The high road to sustainable growth London: CIPD

National Audit Office (2009) Train to Gain: Developing the skills of the workforce London: $\mathrm{NAO}$

Newton B, Miller L, Bates P, Page R and Akroyd K (2006) Learning Through Work: Literacy, language, numeracy and IT skills development in low-paid, low-skilled workplaces Institute for Employment Studies: Report 433

O'Brien P and Pike A (2015) City Deals, Decentralisation and the Governance of Local Infrastructure Funding and Financing in the UK. National Institute Economic Review 2015, 233(1), 14-26.

OECD (2012) Better Skills, Better Jobs, Better Lives: A Strategic Approach to Skills Policies Paris: OECD Publishing

OECD (2014) Job creation and local economic development. Paris: OECD Publishing

Payne J (2004) 'Re-evaluating the Finnish Workplace Development Programme: Evidence from two projects in the municipal sector' Economic and Industrial Democracy, 25(4): 485-524

Payne, J. (2007) Skills in Context: What Can the UK Learn from Australia's Skill Ecosystem Projects? SKOPE Research Paper no 70. Oxford: SKOPE

Payne J and Keep E (2011) One step forward, two steps back? Skills policy in England under the Coalition Government SKOPE Research Paper no 102. Oxford: SKOPE

Peck F, Connolly S, Durnin J and Jackson K (2013) Prospects for 'place-based' industrial policy in England: The role of Local Enterprise Partnerships Local Economy 28(78): 828-841.

Ray K, Foley B and Hughes C (2014) Rising to the Challenge: A policy agenda to tackle low pay. London: The Work Foundation

Sheffield City Region Growth Deal https://www.gov.uk/government/uploads/system/uploads/attachment_data/fil e/327610/28_Sheffield_City_Region_Growth_Deal.pdf (accessed 05 November 2014)

Sheffield LEP (2013) Economic Overview http:/ / sheffieldcityregion.org.uk/wpcontent/uploads/2013/08/Economic-Overview-web-version.pdf

Sissons P and Jones K (2014) How can local skills strategies help low earners? York: Joseph Rowntree Foundation 
SQW (2010) Best Strategies in Skills Utilisation SQW Consulting

Sung J and Ashton D (2014) Skills in Business: The role of business strategy, sectoral skills development and skills policy London: SAGE

UKCES (2010) High Performance Working: A Policy Review London: UKCES

UKCES (2014) UK Commission's Employer Skills Survey 2013: UK Results London: UKCES

UKCES Employer Skills Survey 2007, 2009, 2011, 2013. Available at http://www.ukces.org.uk/ourwork/employer-surveys

Wilson R and Hogarth T (2003) Tackling the Low Skills Equilibrium: A Review of Issues and Some New Evidence London: Department of Trade and Industry

Wright J and Sissons P (2012) The Skills Dilemma: Skills under-utilisation and low-wage work London: The Work Foundation

\footnotetext{
i See:

https://www.gov.uk/government/uploads/system/uploads/attachment_data/file/398872/28_Sheffield_ City_Region_Growth_Deal.pdf

ii http://www.theguardian.com/politics/2008/dec/03/peter-mandelson-hugo-young-lecture

iii UKCES is being disbanded by the Government in 2016.

iv Of course within areas different firms will have different orientations and issues around their ability to access and use skills

v 'Better skills' is also one of three key foci of the Sheffield City Region Growth Deal, alongside improving transport, employment and housing sites and delivering world class business support. As part of the deal for 'better skills' the SCR's Growth Deal includes investment in skills infrastructure, a Sheffield City Region Skills Bank, and improving links with business.

vi https://www.nomisweb.co.uk/reports/lmp/lep/1925185559/report.aspx\#tabrespop

vii Source: Personal communication with local stakeholders

viii One specific local concern in relation to skills is over a potential skills gap emerging at a technician level due to workforce retirements (MADE in Sheffield, 2012)
} 